\title{
Implementasi Model Pembelajaran Inkuiri dengan Berbantuan Media Gambar untuk Meningkatkan Prestasi Belajar Agama Hindu
}

\section{Nyoman Intaran}

SD N 3 Tianyar, Karangasem, Indonesia

A R T I C L E I N F O

Article history:

Received 19

November 2017

Received in revised form

6 Januari 2018

Accepted 12 Januari 2018

Available online 20

Februari 2018

Kata Kunci:

Model Pembelajaran

Inkuiri,

Media Gambar,

Prestasi Belajar.

Keywords:

Inquiry Learning

Model, Image Media,

Learning

Achievement.
A B S T R A K

Penelitian ini dilaksanakan di SD Negeri 3 Tianyar di Kelas II Semester I Tahun Pelajaran 2016/2017 yang prestasi belajarnya untuk mata pelajaran agama Hindu sangat rendah. Tujuan penelitian tindakan kelas ini adalah untuk meningkatkan prestasi belajar agama Hindu siswa menggunakan model pembelajaran inkuiri berbantuan media gambar. Metode pengumpulan datanya adalah tes prestasi belajar. Metode analisis datanya adalah deskriptif. Hasil yang diperoleh dari penelitian ini adalah model pembelajaran inkuiri berbantuan media gambar dapat meningkatkan prestasi belajar agama Hindu siswa. Ini terbukti dari hasil yang diperoleh pada awalnya 65, pada siklus I menjadi 67,92 dan pada siklus II menjadi 72,92. Kesimpulan yang diperoleh dari penelitian ini adalah model pembelajaran Inkuiri berbantuan Media Gambar dapat meningkatkan prestasi belajar agama Hindu siswa Kelas II Semester I SD Negeri 3 Tianyar Tahun Pelajaran 2016/2017.

\section{A B S T R A C T}

This study was conducted at SD Negeri 3 Tianyar at the second grate in the first semester in the school year 2016/2017 who had very low learning achievement in Hinduism. This classroom action research was aimed at increasing learning achievement in Hinduism using picture media-aided inquiry teaching model. The data were collected using a learning ahievement test. The data were analyzed descriptively. The results obtained from this study showed that picture media aided-inquiry teaching model can increase the student's learning achievement in Hinduism. This was shown by the scores obtained at the beginning (65, becoming 67.92 in the first cycle and 72.92 in the second cycle. It can be concluded that picture media-aided inquiry teaching model can increase learning achievement in Hinduism in the second grade students in the first smester at SD Negeri 3 Tianyar in the school year 2016/2017. 


\section{Pendahuluan}

Pendidikan bertujuan untuk mengembangkan potensi peserta didik agar menjadi sumber daya manusia yang berkualitas. Sumber daya manusia berkualitas yang dimaksud adalah manusia yang beriman dan bertaqwa kepada Tuhan Yang Maha Esa, berakhlak mulia, sehat, berilmu, cakap, kreatif, mandiri, berdaya saing dan menjadi warga negara yang demokratis dan bertanggung jawab. Untuk mencapai tujuan tersebut, pemerintah telah berupaya melalui penetapan berbagai peraturan untuk menjamin agar setiap warga negara memperoleh pendidikan yang berkualitas (Hermawati, 2012). Tingkat perkembangan suatu bangsa juga ditentukan oleh unsur-unsur kemajuan dan perkembangan suatu pendidikan. Unsur-unsur itu berupa guru, siswa, sarana dan prasarana pendidikan maupun kebijakan yang telah ditetapkan pemerintah dalam bidang pendidikan. Tercapai tidaknya tujuan pengajaran salah satunya adalah terlihat dari prestasi belajar yang diraih siswa. Dengan prestasi yang tinggi, para siswa mempunyai indikasi berpengetahuan yang baik (Hamdu, 2011). Unsur pendidikan yang sangat berperan penting dalam proses perkembangan pendidikan yaitu guru. Guru merupakan dasar penentu kualitas lulusan siswa yang baik maupun buruk (Dewi, 2013). Penelitian ini dilatarbelakangi oleh adanya kesenjangan antara harapan dengan kondisi nyata di lapangan. Pada kondisi harapan, ada banyak hal yang perlu mendapat perhatian seperti, kemampuan guru memahami model-model pembelajaran, kemampuan guru memahami metode, strategi, teknik serta pendekatan yang dilakukan dalam memberikan pembelajaran di kelas untuk memacu peningkatan mutu pendidikan sesuai harapan. Undang-Undang Republik Indonesia Nomor 20 Tahun 2003 Tentang Sistem Pendidikan Nasional menjelaskan bahwa pendidikan adalah usaha sadar dan terencana untuk mewujudkan suasana belajar dan proses pembelajaran agar peserta didik secara aktif dapat mengembangkan potensi dirinya untuk memiliki kekuatan spiritual keagamaan, pengendalian diri, kepribadian, kecerdasan, akhlak mulia, serta keterampilan yang diperlukan dirinya, masyarakat, bangsa dan negara. Aturan tersebut harus menjadi dasar bagi seorang guru dalam memajukan pendidikan di Indonesia dan sekaligus sebagai harapan dari pihak pemerintah.

Agar terwujudnya tujuan pendidikan yang dicanangkan dalam undang-undang tersebut, diperlukan berbagai upaya aktif dari pendidik dalam proses pembelajaran yang efektif dan berdaya guna. Proses pembelajaran di kelas akan berhasil jika dalam pelaksanaannya guru memahami dengan baik metode, strategi, pendekatan dan model-model pembelajaran yang konstruktivis serta teknik-teknik dalam melakukan pembelajaran. Hal-hal tersebut merupakan persyaratan kompetensi yang harus dimiliki guru sebagai agen pembelajaran pada jenjang pendidikan dasar dan menengah serta pendidikan anak usia dini meliputi: kompetensi pedagogik, kepribadian, profesional, dan sosial dalam memajukan pendidikan.

Penjelasan yang dapat disampaikan lebih lanjut tentang kompetensi-kompetensi tersebut adalah 1) Kompetensi pedagogik merupakan kemampuan yang berkenaan dengan pemahaman peserta didik dan pengelola pembelajaran yang mendidik dan dialogis. Secara substantif kompetensi ini mencakup kemampuan pemahaman terhadap peserta didik, perancangan dan pelaksanaan pembelajaran, evaluasi hasil belajar, dan pengembangan peserta didik untuk mengaktualisasikan berbagai potensi yang dimilikinya; 2) Kompetensi kepribadian merupakan kemampuan personal yang mencerminkan kepribadian yang yang mantap, arif, dewasa, dan berwibawa, menjadi teladan bagi peserta didik, dan berakhlak mulia; 3) Kompetensi profesional merupakan kemampuan yang berkenaan dengan penguasaan materi pembelajaran bidang studi secara luas dan mendalam yang mencakup penguasaan substansi isi materi kurikulum mata pelajaran di sekolah dan substansi keilmuan yang menaungi materi kurikulum tersebut, serta menambah wawasan keilmuan sebagai guru; 4) Kompetensi sosial berkenaan dengan kemampuan pendidik sebagai bagian dari masyarakat untuk berkomunikasi dan bergaul secara efektif dengan peserta didik, sesama pendidik, tenaga kependidikan, orangtua/wali peserta didik, dan masyarakat sekitar. Untuk hal-hal tersebut bukanlah merupakan hal yang gampang.

Menurut Hanif, jika dilihat dari kompetensinya terdapat empat peringkat pembagian kompetensi bagi guru: 1) profesional; 2) tukang ngajar; 3) juru ngajar; dan 4) pramu bahan ajar. Guru sebagai tukang, bekerja mengikuti pola atau model tertentu yang sudah dihafal. Sebagai juru, bekerja berdasarkan petunjuk atasan untuk mengerjakan pekerjaan teknis. Pramu, bekerja berdasarkan perintah atasan untuk menyajikan sesuatu. Sedangkan profesional, guru bekerja berdasarkan lima prinsip kerja profesi: 1) disiplin ilmu yang diperoleh saat mengikuti pendidikan, 2) pelatihan profesi, 3) pengalaman yang panjang dalam melaksanakan tugas profesi, 4) pengembangan profesi melalui forum-forum ilmiah, dan 5) berperilaku sesuai kode etik profesinya. Jadi, guru yang mengajar dengan mengikuti pola/model yang dihafal, ini tukang mengajar. Guru yang mengajar berdasarkan juklak/juknis atasan, ini juru ngajar. Guru yang mengajar sekadar menyampaikan bahan ajar yang diperintahkan atasannya, ini pramu bahan ajar. Sedangkan guru profesional adalah guru yang sangat ahli mengembangkan dan mengimplementasikan model pembelajaan yang bermutu dengan berpijak pada lima prinsip kerja profesi tersebut secara 
mandiri. Cara kerjanya seperti dokter. Dalam bekerja, dokter tidak berdasarkan model/pola tertentu, juklak/juknis, atau perintah direktur rumah sakitnya tapi berdasarkan lima prinsip kerja profesi tersebut secara mandiri.

Semua penyampaian harapan di atas diperuntukkan bagi semua guru untuk mengukur pribadi mereka masing-masing, dimana mereka berada, pada peringkat mana mereka dikategorikan, dan upaya apa yang dapat mereka usahakan untuk memperbaiki peringkat tersebut menjadi ideal. Apa yang digambarkan di atas mungkin ada banyak benarnya, salah satu yang terkadang guru lalai adalah perlakuan subyektif kepada siswa. Seringkali guru hanya memperhatikan siswa-siswa yang bisa membawa daya tarik tersendiri saja, sementara siswa yang terlihat sederhana dimarginalkan. Implikasi yang dapat dilihat, terkadang prestasi siswa yang satu dengan yang lain sangat mencolok. Guru diajarkan pemahaman tentang seorang murid yang membutuhkan bantuan dalam menapaki tahapan perkembangannya, guru harus memberikan pengetahuan bagaimana untuk mampu meningkatkan prestasi siswa. Dalam pelaksanaan proses pembelajaran terkadang kurang memberikan kesempatan kepada peserta didik secara individual untuk memperoleh perlakuan yang sama dalam berbagai mata pelajaran, untuk mengembangkan kemampuan berpikir holistik (menyeluruh), kreatif, objektif, dan logis mereka, belum memperhatikan perbedaan kemampuan secara individu yang mengakibatkan masih banyak siswa yang belum bisa mencapai ketuntasan belajar secara individual dikarenakan perbedaan perlakuan.

Kondisi di pihak guru yang harus betul-betul dipahami yang banyak berpengaruh terhadap kemauan guru untuk memberikan pengetahuan yang terbaik bagi setiap siswa, termasuk kemauan guru itu sendiri untuk menyiapkan bahan yang lebih baik, menerapkan metode-metode ajar yang efektif banyak berdampak pada belum tercapainya tingkat ketuntasan belajar siswa secara individual. Apabila guru mampu memahami hal-hal tersebut, maka guru akan mampu melaksanakan pembelajaran dengan baik dan mau giat memperbaiki kondisi yang ada agar tingkat perkembangan kemampuan peserta didik tidak mengalami gangguan pada tahapan berikutnya. Namun berdasarkan hasil observasi awal diperoleh kenyataan hasil prestasi belajar agama siswa kelas II di semester I tahun pelajaran 2012/2013 baru mencapai nilai rata-rata 65. Dapat disadari bahwa hasil tersebut masih sangat jauh dari kriteria ketuntasan minimal mata pelajaran agama Hindu di SD Negeri 3 Tianyar.

Berdasarkan kenyataan tersebut, usaha yang bisa dilakukan adalah meningkatkan prestasi belajar peserta didik dengan memperbaiki proses pembelajaran menggunakan model pembelajaran inkuiri, pilihan yang dapat diambil adalah dengan pemberian tugas-tugas secara individual yang mampu menuntun anak-anak mencapai penguasaan terhadap topik-topik bahasan sebelum semua bahan dapat dipahami. Pembelajaran dengan model pembelajaran inkuiri terbimbing disertai teknik peta konsep dapat membuat siswa lebih mudah untuk memahami materi yang diajarkan karena mengajak siswa untuk terlibat langsung dalam pembelajaran dan memperoleh pengetahuan dari pengalaman langsung dan siswa diharuskan membuat peta konsep secara individu agar mudah diingat dan mudah dipelajari kembali sehingga hasil belajar siswa tinggi (Putri, 2016). Natalia (2013) bahwa model inkuiri terbimbing dapat mempengaruhi hasil belajar Biologi dalam kompetensi suatu keahlian siswa SMA yang menunjukkan pengaruh yang signifikan terhadap hasil belajar siswa SMA Negeri 5 Pekanbaru, selain itu pada penelitian Nurmasanti (2013) juga pernah meneliti model pembelajaran inkuiri terbimbing disertai teknik peta konsep dapat meningkatkan hasil belajar dan retensi hasil belajar siswa kelas eksperimen lebih baik dari kelas kontrol. Peneliti berkeinginan untuk menerapkannya dalam pembelajaran sebagai solusi dalam mengatasi masalah prestasi belajar Agama Hindu siswa kelas II semester I di SD Negeri 3 Tianyar akibat ketidaksamaan perlakuan yang diberikan kepada masing-masing siswa. Hal inilah yang membuat peneliti ingin mencoba Penelitian Tindakan Kelas dengan judul "Implementasi Model Pembelajaran Inkuiri Dengan Berbantuan Media Gambar Untuk Meningkatkan Prestasi Belajar Agama Hindu Siswa Kelas II Semester I SD Negeri 3 Tianyar Tahun Pelajaran 2012/2013".

\section{Metode}

Untuk mengumpulkan prestasi belajar siswa seperti yang diharapkan dalam penelitian ini dilakukan dengan memanfaatkan tes prestasi belajar. Adapun data hasil penelitian ini yang dipergunakan dalam menganalisis adalah analisis deskriptif. Untuk data kuantitatif dianalisis dengan mencari mean, median, modus, membuat interval kelas, dan melakukan penyajian dalam bentuk tabel dan grafik. Indikator keberhasilan penelitian yang diusulkan dalam penelitian ini pada siklus I mencapai nilai rata-rata 70 dengan ketuntasan belajar $80 \%$ dan pada siklus II mencapai nilai rata-rata 70 atau lebih dengan ketuntasan belajar minimal $80 \%$. 
Yang dijadikan lokasi penelitian adalah SD Negeri 3 Tianyar. Sekolah ini berada dilokasi yang jauh dari keramaian sehingga proses pembelajaran mampu dilakukan dengan lebih baik. Bagaiman pelaksanaan penelitian ini dapat dilihat pada Gambar 1 berikut.

Pelaksanaan penelitian tindakan kelas ini mempergunakan rancangan dari Mc. Kernan.

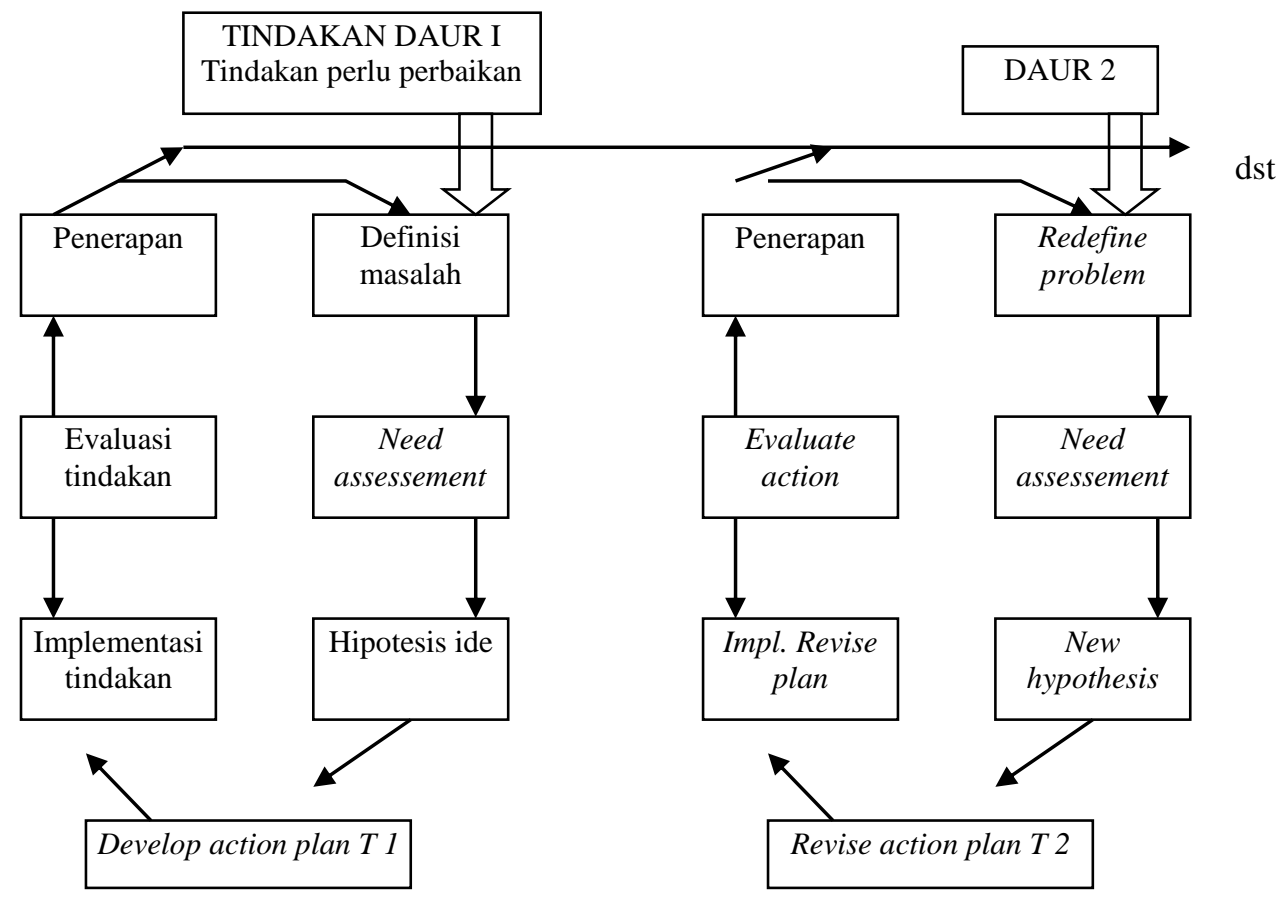

Gambar 01. Penelitian Tindakan Model Mc. Kernan, 1991 (dalam Sukidin, Basrowi, Suranto, 2002: 54)

Pelaksanaannya di kelas sesuai gambar di atas, adalah tindakan daur I dilakukan definisi masalah dilanjutkan dengan pelaksanaan di lapangan, dirumuskan hipotesisnya, dikembangkan hipotesis tersebut, diimplementasikan, dievauasi dari hasil yang didapat dan evaluasi diterapkan. Langkahlangkah pada daur II atau siklus II sama dengan yang di siklus I yaitu dimulai dengan adanya suatu permasalahan yang baru, didefinisikan masalahnya, dibuat hipotesisnya direvisi, selanjutnya dilakukan implementasi di lapangan, dievaluasi, kemudian hasil yang didapat merupakan penerapan baru apabila masih adalah masalah. Penelitian ini mengambil subjek penelitian yaitu siswa kelas II SD Negeri 3 Tianyar semester I tahun pelajaran 2013/2014, seperti terlihat pada tabel berikut.

Tabel 01. Nama-nama Siswa Kelas II Semester I SD Negeri 3 Tianyar Tahun Pelajaran 2012/2013

\begin{tabular}{cc}
\hline Nomor Subjek Penelitian & Nama Siswa \\
\hline 1 & Ni Komang Srikandi \\
\hline 2 & I Ketut Gunawan \\
\hline 3 & I Ketut Nada \\
\hline 4 & I Nyoman Suantara \\
\hline 5 & I Gede Gunawan \\
\hline 6 & I Gede Dika Suryanata \\
\hline 7 & Ni Nyoman Sukanti \\
\hline 8 & Ni Nyoman Sukmawati \\
\hline 9 & Ni Kadek Ira Dianawati \\
\hline 10 & Ni Luh Ari Astuti \\
\hline 11 & Ni Nengah Riani \\
\hline 12 & I Ketut Jaya Perwata
\end{tabular}

Objek penelitian ini adalah peningkatan prestasi belajar agama Hindu siswa kelas II semester I tahun pelajaran 2012/2013 SD Negeri 3 Tianyar setelah diterapkan model pembelajaran inkuri 
berbantuan media gambar dalam pembelajaran. Tabel berikut menjelaskan pelaksanaan penelitian yang dilakukan, yaitu dari bulan Juli sampai bulan Novmber tahun 2012.

\section{Hasil dan Pembahasan \\ Hasil Penelitian}

Tindakan yang dilakukan dalam penelitian ini adalah kegiatan untuk meningkatkan prestasi belajar agama Hindu siswa kelas II semester I tahun pelajaran 2012/2013 SD Negeri 3 Tianyar. Setelah data diperoleh, selanjutnya disampaikan deskripsi yang lengkap terhadap apa yang sudah dilakukan baik dalam perencanaan, pelaksanaan, observasi, dan refleksi. Dalam refleksi dilakukan analisis yaitu analisis kuantitatif. Analisis kuantitatif dilakukan sehubungan dengan data yang dihasilkan adalah data berbentuk angka.

Siklus I terdiri dari tiga tahapan yaitu tahapan pertama adalah rencana tindakan I, langkah-langkah dalam rencana tindakan yaitu, a) memahami lebih dalam sintaks pembelajaran yang digunakan, b) Mencari lebih banyak teori tentang bimbingan yang akan dilakukan, c) merencanakan merubah situasi belajar yang lebih baik, d) menyusun rencana pelaksanaan pembelajaran yang berisi langkah-langkah model pembelajaran inkuiri, e) menyiapkan gambar-gambar sebagai media pembelajaran. Tahp kedua adalah pelaksanaan tindakan I. Kegiatan pembelajaran agama Hindu dilaksanakan sesuai teori yaitu langkah-langkah model pembelajaran inkuiri yaitu, a) menjelaskan materi ajar yaitu Tri Mala melalui gambar-gambar, b) menjelaskan tujuan dan hasil belajar yang diharapkan tercapai oleh siswa, c) menjelaskan pokok-pokok kegiatan yang harus dilakukan oleh siswa untuk mencapai tujuan. Mulai dari menjelaskan merumuskan masalah sampai dengan merumuskan kesimpulan, d) Memotivasi siswa dengan menjelaskan pentingnya topik dan pentingnya kegiatan belajar, e) Menyuruh siswa untuk merumuskan masalah sendiri dari topik yang ada, sehingga siswa memiliki motivasi belajar yang tinggi manakala dilibatkan dalam merumuskan masalah yang dikaji, f) Mendorong siswa untuk mencari jawaban yang tepat dari masalah tersebut, g) Mendampingi siswa dalam proses mencari jawaban dari masalah agar siswa memperoleh pengalaman yang sangat berharga. Perolehan pengalaman yang sangat berharga dimaksudkan untuk mengembangkan mental peserta didik melalui proses berpikir, h) Melakukan hipotesis yaitu dengan mengkaji jawaban sementara dari permasalahan, i) Peneliti mengembangkan kemampuan berhipotesis siswa dengan mengajukan berbagai pertanyaan yang dapat mendorong peserta didik untuk dapat merumuskan jawaban sementara atau dapat merumuskan berbagai perkiraan kemungkinan jawaban dari suatu permasalahan yang dikaji, j) Mengumpulkan informasi untuk menguji hipotesis yang diajukan, k) Menentukan jawaban yang dianggap diterima sesuai dengan informasi yang diperoleh, l) Mendeskripsikan temuan yang diperoleh berdasarkan hasil pengujian hipotesis, dan $\mathrm{m}$ ) Mengakhiri pembelajaran dengan salam penutup. Tahap Ketiga dalam Siklus I adalah Observasi/Pengamatan Siklus I, pelaksanaan observasi dilakukan dengan urutan-urutan: a) Masuk ke kelas dengan mengucapkan salam, berlanjut dengan memberi penjelasan tentang tes yang harus dikerjakan, membagikan tes serta lembar kertas yang digunakan untuk menjawab soal-soal tes pada siswa, b) Penyampaian pada siswa, bahwa setelah jawaban mereka diperiksa, hasilnya akan dibagikan pada mereka dan menjelaskan; bagi mereka yang nilainya belum mencapai KKM yang dituntut pada mata pelajaran ini yaitu 70 akan diberikan remedial dan bagi yang sudah mencapai KKM atau melebihi akan diberikan pengayaan, c) Setelah pelaksanaan tes, guru kembali ke kantor untuk melanjutkan pemeriksaan terhadap jawaban yang dibuat siswa, d) Dalam pemeriksaan jawaban siswa, di ruang guru peneliti mendiskusikan jawaban-jawaban siswa dengan guru teman sejawat agar dapat memberi penilaian yang objektif.

Tabel 04. Prestasi Belajar Agama Hindu Siswa Kelas II Semester I SD Negeri 3 Tianyar Tahun Pelajaran 2012/2013 Siklus I

\begin{tabular}{cll}
\hline Nomor Subjek Penelitian & Nilai & Keterangan \\
\hline 1. & 70 & Tuntas \\
\hline 2. & 60 & Belum tuntas \\
\hline 3. & 60 & Belum tuntas \\
\hline 4. & 85 & Tuntas \\
\hline 5. & 60 & Belum tuntas \\
\hline 6. & 70 & Tuntas \\
\hline 7. & 60 & Belum tuntas \\
\hline 8. & 70 & Tuntas \\
\hline 9. & 70 & Tuntas \\
\hline 10. & 70 & Tuntas \\
\hline
\end{tabular}

I Nyoman Intaran/ Implementasi Model Pembelajaran Inkuiri dengan Berbantuan Media Gambar untuk Meningkatkan Prestasi Belajar Agama Hindu 


\begin{tabular}{lll}
\hline Nomor Subjek Penelitian & Nilai & Keterangan \\
\hline 11. & 70 & Tuntas \\
\hline \multicolumn{1}{c}{ J2. } & 70 & Tuntas \\
\hline Jumlah Nilai & 815 & \\
\hline Rata-rata (Mean) & 67,92 & \\
\hline Jumlah (Kriteria Ketuntasan Minimal) & 70 & \\
\hline Jumlah Siswa yang Mesti Diremidi & 4 & \\
\hline Presentase Ketuntasan Belajar & 8 & \\
\hline
\end{tabular}

Refleksi Siklus I, data yang diperoleh selama melaksanakan penelitiaan merupakan data dari keberhasilan yang telah dicapai. Untuk memperjelas apa yang telah dicapai diperlukan untuk menyampaikan refleksi. Dari refleksi yang dibuat akan menjadi jelas keberhasilan yang dicapai oleh seorang peneliti. Untuk itu peneliti paparkan hal-hal berikut.

Tabel 05. Data Kelas Interval Siklus I

\begin{tabular}{lcccc}
\hline $\begin{array}{l}\text { No } \\
\text { Urut }\end{array}$ & Interval & $\begin{array}{l}\text { Nilai } \\
\text { Tengah }\end{array}$ & $\begin{array}{l}\text { Frekuensi } \\
\text { Absolut }\end{array}$ & $\begin{array}{l}\text { Frekuensi } \\
\text { Relatif }\end{array}$ \\
\hline 1 & $60-66$ & 63 & 4 & 33,33 \\
\hline 2 & $67-73$ & 70 & 7 & 58,33 \\
\hline 3 & $74-80$ & 77 & 0 & 0,00 \\
\hline 4 & $81-87$ & 84 & 1 & 8,33 \\
\hline Total & & & 12 & 100 \\
\hline
\end{tabular}

- Penyajian dalam bentuk grafik/histogram

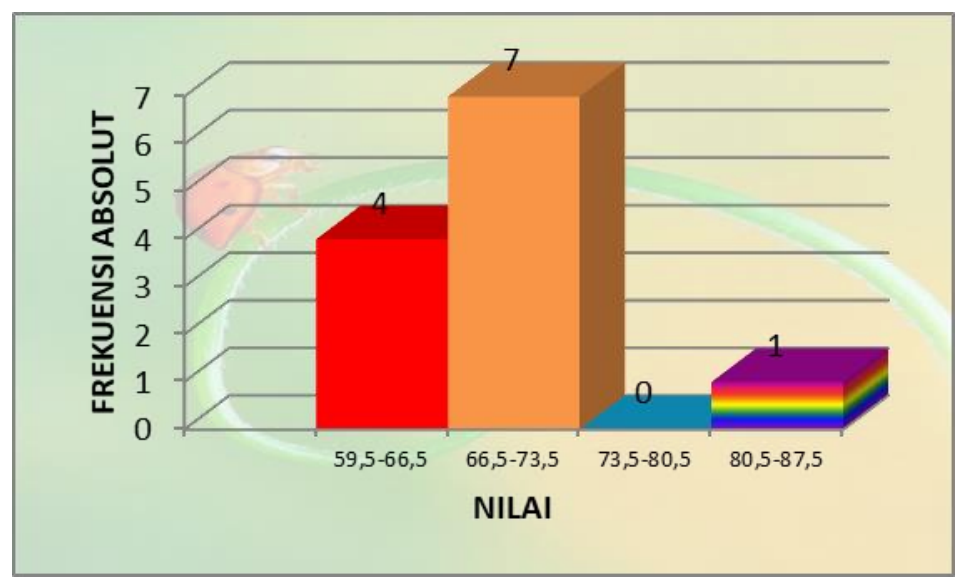

Gambar 02. Histogram Prestasi Belajar Agama Hindu Siswa Kelas II Semester I SD Negeri 3 Tianyar Tahun Pelajaran 2012/2013 Siklus I

Berdasarkan data yang didapat dan telah dilakukan perhitungan dengan mencari mean, median, dan modus diperoleh nilai perbandingan yang cukup baik dibandingkan dengan data awal. Kalau data awal memperoleh nilai rata-rata siswa sebesar 65 di siklus I terjadi peningkatan menjadi 67,92 sedangkan untuk mediannya adalah data awal sebesar 65 dan data siklus I sebesar 70 dan modus untuk data awal sebesar 70, untuk siklus I juga sebesar 70. Data ini menggambarkan bahwa peningkatan terjadi setelah diterapkannya model pembelajaran inkuiri. Model pembelajaran ini meningkatkan kemampuan ingatan dan pemahaman siswa terhadap materi pembelajaran, karena informasi yang mereka peroleh berdasarkan pengalaman belajar mereka yang autentik ketika siswa menemukan sendiri jawaban akan pertanyaan-pertanyaan yang juga mereka ajukan sendiri saat proses pembelajaran. Pemahaman yang mendalam oleh siswa terhadap materi pembelajaran juga membuat mereka lebih mudah mengaplikasikan pengetahuan itu pada situasi yang baru. 
Keberhasilan yang digambarkan mengenai peningkatan nilai rata-rata dari data awal ke siklus I ternyata belum memenuhi indikator pencapaian keberhasilan penelitian yang diharapkan. Dari kajian yang dilakukan, kemungkinan guru dan siswa belum begitu terbiasa melaksanakan model pembelajaran inkuiri, maka ada kemungkinan yang besar waktu tidak dapat dimanajemen dengan baik. Pencarian dan pengumpulan informasi bisa saja akan memakan waktu lama atau bahkan jauh lebih lama dibanding jika guru langsung memberi tahu siswa tentang informasi tersebut. Godaan kepada guru untuk segera memberitahu akan menyebabkan model pembelajaran inkuiri yang dilaksanakan menjadi tidak berfungsi dengan baik. Perlu kesabaran guru untuk menahan diri dari memberitahu secara langsung. Semestinya siswa diberikan kesempatan dan waktu lebih banyak untuk belajar secara mandiri dan memanajemen proses belajar mereka, sehingga mereka semakin terbiasa dan waktu berangsur-angsur tak lagi akan menjadi sebuah masalah besar dalam implementasi model pembelajaran ini. Karena itu, peneliti merencanakan perbaikan pada siklus berikutnya.

Siklus II terdiri dari tiga tahapan. Pertama Perencanaan, beberapa hal yang menjadi perencanaan untuk penelitian di siklus II adalah: menyusun secara rinci skenario tindakan yang telah direncanakan dan melakukan pengkajian ulang untuk meminimalisir kemungkinan terjadinya kesalahan. Merencanakan pembelajaran yang menggunakan diskusi kelompok kecil. Membaca langkah-langkah model pembelajaran inkuiri dengan seksama sebelum mengajar agar dalam pelaksanaannya tidak terjadi hal-hal yang tidak diinginkan. Kedua pelaksanaan Tindakan II. Sama seperti pada siklus I, pelaksanaan pembelajaran di siklus II sesuai langkah-langkah model pembelajaran inkuiri. a) memulai pelaksanaan pembelajaran dengan pembelajaran pendahuluan yaitu: mengucapkan salam, melakukan absensi, memotivasi siswa agar giat belajar, melakukan apersepsi, menyampaikan tujuan pembelajaran serta cakupan materi yang sedang diajarkan, b) Menjelaskan materi ajar yaitu pelaksanaan sembahyang dengan media gambar, c) Menjelaskan tujuan dan hasil belajar yang diharapkan tercapai oleh siswa, d) Menjelaskan pokok-pokok kegiatan yang harus dilakukan oleh siswa untuk mencapai tujuan. Mulai dari menjelaskan merumuskan masalah sampai dengan merumuskan kesimpulan, e) Memotivasi siswa dengan menjelaskan pentingnya topik dan pentingnya kegiatan belajar, f) Menyuruh siswa untuk merumuskan masalah sendiri dari topik yang ada, sehingga siswa memiliki motivasi belajar yang tinggi manakala dilibatkan dalam merumuskan masalah yang dikaji, g) Mendorong siswa untuk mencari jawaban yang tepat dari masalah tersebut, h) Mendampingi siswa dalam proses mencari jawaban dari masalah agar peserta didik memperoleh pengalaman yang sangat berharga. Perolehan pengalaman yang sangat berharga dimaksudkan untuk mengembangkan mental siswa melalui proses berpikir, i) Melakukan hipotesis yaitu dengan mengkaji jawaban sementara dari permasalahan, j) Peneliti mengembangkan kemampuan berhipotesis siswa dengan mengajukan berbagai pertanyaan yang dapat mendorong siswa untuk dapat merumuskan jawaban sementara atau dapat merumuskan berbagai perkiraan kemungkinan jawaban dari suatu permasalahan yang dikaji, k) Mengumpulkan informasi untuk menguji hipotesis yang diajukan, l) Menentukan jawaban yang dianggap diterima sesuai dengan informasi yang diperoleh, m) Mendeskripsikan temuan yang diperoleh berdasarkan hasil pengujian hipotesis, n) Mengakhiri pembelajaran dengan salam penutup. Ketiga adalah tahap Observasi/Pengamatan Siklus II, dalam melakukan observasi, peneliti menggunakan jenis instrumen yang telah disusun sebelumnya. Semua tes yang telah dipersiapkan mengacu pada indikator yang diukur. Dalam pelaksanaan tes, peneliti memberi penjelasan tentang kebenaran yang harus mereka kerjakan sesuai petunjuk tes. Setelah tes selesai diperiksa, nilai siswa dimasukkan dalam tabel, kemudian masing-masing nilai dijumlahkan dan dicari rata-rata perolehannya.

Tabel 06. Prestasi Belajar Agama Hindu Siswa Kelas II Semester I SD Negeri 3 Tianyar Tahun Pelajaran 2012/2013 Siklus II

\begin{tabular}{ccc}
\hline Nomor Subjek Penelitian & Nilai & Keterangan \\
\hline 1. & 70 & Tuntas \\
\hline 2. & 80 & Tuntas \\
\hline 3. & 70 & Tuntas \\
\hline 4. & 85 & Tuntas \\
\hline 5. & 70 & Tuntas \\
\hline 6. & 80 & Tuntas \\
\hline 7. & 60 & Belum tuntas \\
\hline 8. & 80 & Tuntas \\
\hline 9. & 70 & Tuntas \\
\hline 10. & 80 & Tuntas \\
\hline 11. & 70 & Tuntas
\end{tabular}




\begin{tabular}{ccc}
\hline Nomor Subjek Penelitian & Nilai & Keterangan \\
\hline 12. & 60 & Belum tuntas \\
\hline Jumlah Nilai & 875 & \\
\hline Rata-rata (Mean) & 72,92 & \\
\hline KKM (Kriteria Ketuntasan Minimal) & 70 & \\
\hline Jumlah Siswa yang Mesti Diremidi & 2 & \\
\hline Jumlah Siswa yang Perlu Diberi Pengayaan & 10 & \\
\hline Prosentase Ketuntasan Belajar & $83 \%$ & \\
\hline
\end{tabular}

a. Refleksi Siklus II

Teknik penyajian dan analisis data kuantitatif dilakukan menggunakan teknik statistik. Terdapat berbagai teknik statistik yang dapat diterapkan untuk menyajikan dan mendeskripsikan data kuantitatif, yaitu rata-rata, median, dan modus.

Tabel 07. Data Kelas Interval Siklus II

\begin{tabular}{|c|c|c|c|c|}
\hline $\begin{array}{c}\text { No } \\
\text { Urut }\end{array}$ & Interval & $\begin{array}{c}\text { Nilai } \\
\text { Tengah }\end{array}$ & $\begin{array}{c}\text { Frekuensi } \\
\text { Absolut }\end{array}$ & $\begin{array}{c}\text { Frekuensi } \\
\text { Relatif }\end{array}$ \\
\hline 1 & $60-66$ & 63,0 & 2 & 16,67 \\
\hline 2 & $67-73$ & 70,0 & 5 & 41,67 \\
\hline 3 & $74-80$ & 77,0 & 4 & 33,33 \\
\hline 4 & $81-87$ & 84,0 & 1 & 8,33 \\
\hline Total & & & 12 & 100 \\
\hline
\end{tabular}

- Penyajian dalam bentuk grafik/histogram

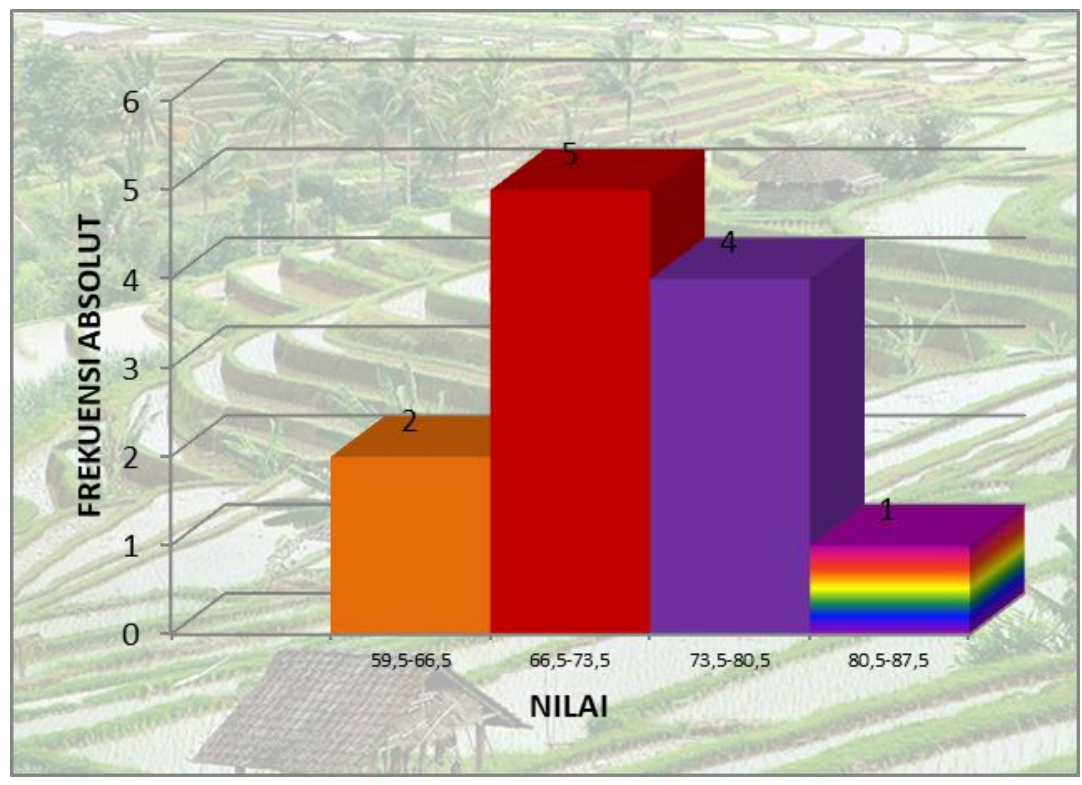

Gambar 03. Histogram Prestasi Belajar Agama Hindu Siswa Kelas II Semester I SD Negeri 3 Tianyar Tahun Pelajaran 2012/2013 Siklus II

Data yang didapat setelah dilakukan perhitungan dengan mencari mean, median, dan modus diperoleh peningkatan nilai rata-rata siswa dari siklus I. Kalau siklus I memperoleh nilai rata-rata siswa sebesar 67,92, di siklus II terjadi peningkatan menjadi 72,92. Sedangkan untuk mediannya adalah siklus I sebesar 70 dan data siklus II sebesar 70 dan modus untuk siklus I sebesar 70, untuk siklus II sebesar 70. Hasil tersebut menggambarkan bahwa peningkatan terjadi setelah diterapkan model pembelajaran inkuiri. Dengan memanfaatkan langkah-langkah model pembelajaran inkuiri, siswa-siswa menjadi terlatih dan terbiasa menghadapi permasalahanpermasalahan baru yang ditemui. Mereka juga mempunyai keterampilan-keterampilan khusus untuk memecahkan masalah tersebut. Model pembelajaran inkuiri membantu guru secara 
simultan meningkatkan motivasi belajar siswa. Dalam model pembelajaran ini, siswa selalu diberikan kesempatan untuk mempelajari informasi-informasi yang mereka minati atau memecahkan masalah-masalah yang mereka formulasikan sendiri lewat pertanyaan-pertanyaan yang diajukan di awal pembelajaran. Secara alamiah motivasi siswa akan terbangun karena apa informasi yang dipelajari atau masalah yang sedang dipecahkan merupakan hal-hal yang menarik perhatian dan pemikiran mereka.

Keberhasilan yang digambarkan mengenai peningkatan nilai rata-rata dari data awal sampai siklus II ternyata telah memenuhi indikator pencapaian keberhasilan penelitian yang diharapkan. Dalam penelitian ini indikator keberhasilan penelitian yang ditetapkan adalah jika 80\% siswa atau lebih telah mencapai nilai KKM (70) maka penelitian dinyatakan berhasil dan tidak dilanjutkan ke siklus berikutnya.

Tindakan yang dilakukan telah maksimal memberikan efeknya bagi peningkatan proses dan hasil belajar siswa. Dari kajian yang dilakukan guru, dengan mengoptimalkan proses pembelajaran secara kooperatif dan komunikatif, dengan demonstrasi, tanya jawab, pengulangan dengan saling bertanya antar teman, motivasi, nasehat, arahan, bimbingan, dan fasilitasi dari guru semakin meningkatkan semangat belajar pada diri siswa dan semakin meningkatkan prestasi belajar agama Hindu.

\section{Pembahasan}

Gambaran Pelaksanaan Prasiklus/Awal

Deskripsi awal telah menunjukkan rendahnya prestasi belajar agama Hindu siswa yang diakibatkan oleh faktor-faktor luar dan faktor-faktor dari dalam diri guru sendiri. Faktor-faktor tersebut telah dipahami betul dan pelan-pelan diperbaiki agar proses pembelajaran tidak dipengaruhi oleh faktor-faktor tersebut dengan cara membuat perencanaan yang lebih baik pada siklus berikutnya. Dari faktor siswa tentang kurangnya motivasi orang tua dalam mengarahkan anak-anak mereka untuk mau giat belajar dilakukan dengan memberi pengarahan lewat penyampaian yang dilakukan kepala sekolah terhadap orang tua siswa.

Pembahasan Hasil yang Diperoleh dari Siklus I

Dari hasil pengamatan dan refleksi yang telah dilakukan pada siklus I, dalam upaya pembenahan proses pembelajaran di kelas dapat disampaikan bahwa pelaksanaan pembelajaran dengan memanfaatkan pembelajaran inkuiri telah menunjukkan perubahan pada prestasi belajar yang dicapai siswa dan juga perilaku belajar yang ditunjukkan di kelas. Pada saat penerapan pembelajaran inkuiri terlihat bahwa pelaksanaan proses pembelajaran sudah berjalan dengan lancar. Banyak siswa sudah meningkat aktivitas dan kreativitas belajarnya, serta hasil nilai rata-rata siswa secara klasikal juga sudah menunjukkan perbaikan. Hal ini menjadi interpretasi bahwa perjalanan penelitian dengan penerapan strategi inkuiri sudah cukup baik. Peningkatan yang terjadi menunjukkan bahwa apa yang dicari siswa berupa pengetahuan dan pemahaman sudah berhasil ditemukan sehingga siswa dapat menyelesaikan soal dan masalah yang ditugaskan guru. Keberhasilan tersebut sesuai dengan apa yang dinyatakan oleh Sanjaya (2006: 199) bahwa apabila strategi Inkuiri dilaksanakan dalam proses pembelajaran akan dapat mengembangkan kemampuan berpikir siswa melalui interaksi dalam kelompok. Strategi pembelajaran inkuiri berorientasi pada proses dan hasil belajar. Keberhasilan dari proses pembelajaran dengan menggunakan strategi inkuiri bukan ditentukan oleh sejauh mana siswa menguasai materi pelajaran, akan tetapi sejauh mana siswa beraktivitas mencari dan menemukan sesuatu yang berhubungan dengan materi yang dipelajari.

Walaupun terlihat sudah terjadi peningkatan dalam pelaksanaan siklus I, namun masih ditemukan beberapa kelemahan dalam pelaksanaan di kelas. Kelemahan yang dapat disampaikan yaitu penggunaan waktu yang belum efektif, konstruksi, kontribusi siswa belum maksimal, fakta ini akan dijadikan acuan kebenaran data, validasi internal validitas eksternal berupa penggunaan teori-teori yang mendukung dan reliabilitas data penelitian ini dapat peneliti yakini karena hal itu merupakan ketepatan peneliti memilih instrumen. Faktor-faktor yang berpengaruh belum maksimalnya pembelajaran pada siklus I ini adalah karena peneliti baru satu kali mencoba model ini. Cara pemecahan masalahnya adalah pengelolaan kelas yang lebih baik, lebih berkualitas, dan mengupayakan agar sarana pendukung pembelajaran lebih ditingkatkan atau lebih variatif.

Dari gambaran pelaksanaan yang telah dilakukan ternyata hasil yang diperoleh pada siklus I ini sudah lebih baik dari hasil awal yang baru mencapai nilai rata-rata. 65 dengan ketuntasan belajar $50 \%$. Pada siklus I ini sudah mencapai peningkatan sedikit lebih tinggi yaitu dengan rata-rata 67,92 dan ketuntasan belajar $67 \%$. Namun hasil tersebut belum maksimal karena tuntutan indikator keberhasilan penelitian adalah agar siswa mampu memperoleh rata-rata minimal 70 dengan ketuntasan belajar $80 \%$. Oleh karenanya penelitian ini masih perlu untuk dilanjutkan. 
Pembahasan Hasil yang Diperoleh dari Pelaksanaan Siklus II

Perolehan hasil dari kegiatan penelitian pada siklus II ini terbukti telah menunjukkan bahwa kemampuan siswa dalam mengikuti pelajaran sudah cukup baik. Ini terbukti dari rata-rata nilai siswa mencapai 72,92 dengan ketuntasan belajar 83\%. Hasil ini menunjukkan bahwa implementasi model inkuiri berbantuan media gambar telah berhasil meningkatkan kemampuan siswa menempa ilmu sesuai harapan. Model pembelajaran inkuiri merupakan model yang cocok bagi siswa apabila guru menginginkan mereka memiliki kemampuan melakukan analisis, sintesis, berargumentasi, mengeluarkan pendapat secara lugas. Model pembelajaran mampu memupuk kemampuan intelektual siswa, mendorong siswa untuk mampu menemukan sendiri, menempatkan siswa pada posisi sentral dan mengupayakan agar siswa mampu belajar lewat penemuan agar materi yang dipelajari dapat diingat lebih lama.

Hasil penelitian ini ternyata telah memberi efek utama bahwa model yang diterapkan dalam proses pembelajaran berpengaruh secara signifikan terhadap prestasi belajar siswa. Temuan ini membuktikan bahwa guru sudah tepat memilih model dalam melaksanakan proses pembelajaran karena pemilihan model merupakan hal yang tidak boleh dikesampingkan. Hal ini sejalan pula dengan temuan-temuan peneliti lain seperti yang dilakukan oleh Isyfiyyati (2011) yang berjudul: Implementasi Pendekatan Pembelajaran Inkuiri Untuk Meningkatkan Hasil Belajar Siswa, menemukan bahwa siswa yang diajarkan dengan pendekatan inkuiri mulai dikenalkan mengenai keterampilan-keterampilan dasar dalam kerja ilmiah. Selain itu Juniati (2017) mengemukakan model pembelajaran Inkuiri dapat meningkatkan hasil belajar IPA siswa kelas IV di SD No. 5 Gulingan tahun pelajaran 2016/2017.

Apalagi didukung dengan metode praktikum dan diskusi, siswa dapat terlatih untuk menganalisis suatu permasalahan dengan cermat sehingga siswa dengan sendirinya dapat mengembangkan daya kreativitas siswa untuk menemukan hubungan baru mengenai konsep yang dimiliki dengan permasalahan yang dihadapi. Karena dengan demikian siswa memperoleh pengalaman belajar yang lebih bermakna sehingga retensi siswa terhadap suatu konsep akan lebih lama untuk diingat.

Melihat perbandingan nilai awal, nilai siklus I dan nilai siklus II, terjadi kenaikan yang signifikan, yaitu dari rata-rata nilai awal 65, meningkat di siklus I menjadi 67,92 dan di siklus II meningkat menjadi 72,92. Peningkatan ini adalah upaya-upaya maksimal yang peneliti laksanakan untuk meningkatkan mutu pendidikan dan kemajuan pendidikan khususnya di SD Negeri 3 Tianyar.

\section{Simpulan dan Saran}

Simpulan merupakan ringkasan hasil penelitian yang bertalian dengan rumusan masalah dan tujuan penelitian. Berdasarkan semua hasil tindakan yang dilakukan, baik siklus I maupun siklus II mulai dari perencanaan, pelaksanaan, pengamatan/observasi dan refleksi dapat disampaikan hal-hal berikut: 1) Pelaksanaan kegiatan awal dimana belum menggunakan model pembelajaran yang dapat meningkatkan kreativitas dan motivasi belajar siswa menyebabkan nilai siswa pada mata pelajaran agama Hindu rendah dengan rata-rata 65 yang masih jauh dari kriteria ketuntasan minimal pada mata pelajaran ini yaitu 70,2) Setelah dilakukan pembelajaran menggunakan langkah-langkah model pembelajaran inkuiri berbantuan media gambar terjadi peningkatan nilai rata-rata siklus I menjadi 67,92. Demikian juga terjadi peningkatan nilai rata-rata siklus II meningkat 72,92, dan 3) Seperti kebenaran tujuan pelaksanaan Penelitian Tindakan Kelas (PTK) yaitu untuk peningkatan prestasi belajar, maka upaya-upaya yang maksimal telah dilakukan mampu memberi jawaban rumusan masalah dan tujuan penelitian ini.

Berdasarkan hasil yang diperoleh seperti uraian di atas, agar proses belajar mengajar di SD Negeri 3 Tianyar lebih efektif dan lebih memberikan hasil yang optimal bagi siswa, disarankan: 1) Agar guru mampu menentukan atau memilih topik yang benar-benar bisa diterapkan dengan model pembelajaran inkuiri sehingga diperoleh hasil yang optimal, 2) Agar mampu meningkatkan prestasi belajar, maka guru hendaknya lebih sering melatih siswa dengan kegiatan penemuan, walau dalam taraf yang sederhana, agar para siswa menjadi berminat terhadap kegiatan yang dilakukan sehingga keaktifan belajar akan meningkat, 3) Peneliti lain diharapkan melakukan penelitian lebih lanjut untuk meneliti bagian-bagian yang belum sempat diteliti.

\section{DAFTAR PUSTAKA}

Arikunto, Suharsimi; Suhardjono; Supardi. 2006. Penelitian Tindakan Kelas. Jakarta: PT Bumi Aksara.

Badan Standar Nasional Pendidikan. 2007. Peraturan Menteri Pendidikan Nasional Republik Indonesia Nomor 41 Tahun 2007. Jakarta: BSNP.

Bhakti, Ahmad Haris. 2009. Tesis. Pengaruh Strategi Pembelajaran Kooperatif Tipe STAD (Student Team Achievement Division) Dan Jigsaw Terhadap Prestasi Belajar Pendidikan Kewarganegaraan 
Ditinjau Dari Minat Belajar Siswa SMP Negeri Di Kecamatan Ngawi. Program Studi Teknologi Pendidikan. Program Pascasarjana Universitas Sebelas Maret. Surakarta.

Dahar, Ratna Wilis. 1989. Teori-Teori Belajar. Jakarta: Penerbit Erlangga.

Dewi, Narni Lestari, Nyoman Dantes, I Wayan Sadia. 2013. Pengaruh Model Pembelajaran Inkuiri Terbimbing Terhadap Sikap Ilmiah Dan Hasil Belajar IPA. e-Journal Program Pascasarjana Universitas Pendidikan Ganesha Jurusan Pendidikan Dasar Volume 3. Djiwandono, Sri Esti Wuryani. 1989. Psikologi Pendidikan (Rev-2). Jakarta: Grasindo.

Habsari, Sri. 2005. Bimbingan \& Konseling SMA kelas XI. Jakarta: Grasindo. http://:pepindogrup.blogspot.com

Hamdu, Ghullam dan Lisa Agustina. 2011. Pengaruh Motivasi Belajar Siswa Terhadap Pestasi Belajar Ipa Di Sekolah Dasar. Jurnal Penelitian Pendidikan Vol. 12 No. 1.

Hermawati, Ni Wayan Manik. 2012. Pengaruh Model Pembelajaran Inkuiri Terhadap Penguasaan Konsep Biologi Dan Sikap Ilmiah Siswa Sma Ditinjau Dari Minat Belajar Siswa. Program Studi Pendidikan Sains Program Pascasarjana Universitas Pendidikan Ganesha.

Ibrahim dan Nur.2007. Pengertian Metode Inkuiri dan Metode Demonstrasi dalam Pembelajaran Sekolah. [Online]. Tersedia: http://himitsuqalbu.wordpress.com/2011/11/03/metode-inkuiri/.[29 April 2012]

Isyfiyyati. 2011. Implementasi Pendekatan Pembelajaran Inkuiri Untuk Meningkatkan Hasil Belajar Siswa Pada Konsep Kesetimbangan Kimia (Penelitian Tindakan Kelas Pada MA. Al-Falah VI Jakarta). Program Studi Pendidikan Kimia Jurusan Pendidikan Ilmu Pengetahuan Alam Fakultas Ilmu Tarbiyah Dan Keguruan. UIN Syarif Hidayatullah.

Juniati, Ni Wayan dan I Wayan Widiana. (2017). Penerapan Model Pembelajaran Inkuiri Untuk Meningkatkan Hasil Belajar IPA. Jurnal Ilmiah Sekolah Dasar, Universitas Pendidikan Ganesha. Vol.1 (1) pp. 20-29.

Kardi, Soeparman.2003. Merancang Pembelajaran Menggunakan Model Inkuiri. UNS, Surabaya.

Maksum, Ahmad, 2006. Pengaruh Metode Pembelajaran Inquiri terhadap Hasil Belajar Sejarah dan Sikap Nasionalisme Siswa Kelas XI SMA Negeri1 Sukamulia, Lombok Timur, NTB. Tesis. Singaraja. Universitas Pendidikan Ganesha. Program Pascasarjana.

Modern Educators and Lexicographers. 1939. Webster's New American Detionary. New York: 140 Broadway, Books, Inc.

Mulyasa, E. 2006. Kurikulum Berbasis Kompetensi. Bandung: Remaja Rosda Karya

Muzakki. 2012. Thesis. Hubungan Antara Penggunaan Media Pembelajaran Dan Kreativitas Mengajar Guru Dengan Prestasi Belajar Menggunakan Peralatan Kantor Siswa Kelas X SMK N 1 Jogonalan Tahun Ajaran 2011/2012. Universitas Negeri Yogyakarta. eprints.uny.ac.id/8915/

Natalia, M. 2013. Penerapan Model Pembelajaran Inkuiri Terbimbing (Guided Inquiry) untuk Meningkatkan Sikap Ilmiah dan Hasil Belajar Biologi Siswa SMAN 5 Pekanbaru. Jurnal Pembelajaran Biologi. Vol. 1 No. 2: 83-92.

Nurmasanti, K. 2013. Pengaruh Model Inkuiri disertai Teknik Peta Konsep Terhadap Hasil Belajar dan Retensi Hasil Belajar Fisika Kelas XI dalam Pembelajaran Fisika Di Sma Negeri Arjasa. Jurnal Pendidikan Fisika. Vol. 2 No. 2: 251-256.

Nurman, Muhammad, 2006. Pengaruh Penggunaan Metode Pembelajaran Inquiri dan Expositori terhadap SIkap Politik Berdemokrasi dan Prestasi Belajar Siswa pada Pembelajaran PPKn di SMA (Tesis).Singaraja.Institut Keguruan dan Ilmu Pendidikan Negeri Singaraja, Program Pascasarjana. 
Nurman, Muhammad. 2006."Pengaruh Penggunaan Metode Pembelajaran Inkuiri dan Ekspositori Terhadap Sikap Politik Berdemokrasi dan Prestasi belajar Siswa Pada Pembelajaran PPKn di SMA (Studi Eksperimen tentang Pengaruh Metode Pembelajaran Terhadap Sikap Politik Berdemokrasi dan Prestasi Belajar PPKn Siswa di SMA NW Pancor - Lombok Timur). Tesis (tidak diterbitkan) Program Pascasarjana IKIP Negeri Singaraja.

Nuryanto, Apri. 2008. Media Pembelajaran. Yogyakarta: Universitas Negeri Yogyakarta.

Putrayasa, Ida Bagus. 2009. Pembelajaran Bahasa Indonesia Berbasis Inquiri dalam Upaya Meningkatkan Aktivitas, Kreativitas, dan Logikalitas. (Tesis).Singaraja.Institut Keguruan dan Ilmu Pendidikan Negeri Singaraja.

Putrayasa, Ida Bagus. 2009. Pembelajaran Bahasa Indonesia Berbasis Inquiry. Tersedia dalam http://www.ialf.edu/kipbipa/abstracts/ibputrayasa.htm [diakses 19/1/2008].

Putri, Hendrasti Kartika, Indrawati, I Ketut Mahardika. 2016. Model Pembelajaran Inkuiri Terbimbing Disertai Teknik Peta Konsep Dalam Pembelajaran Fisika Di Sma . Jurnal Pembelajaran Fisika, Vol.4 No.4, Maret 2016, hal 321 - 326

Rofidah Nurnaningsih. 2009. Upaya Meningkatkan Kemampuan Membaca Dan Menulis Dengan Media Gambar Pada Pelajaran Bahasa Indonesia Kelas IIb MIN Ngawen Gunungkidul (Pendekatan Penelitian Tindakan Kelas). Skripsi. Program Studi Pendidikan Guru Madrasah Ibtidaiyah Fakultas Tarbiyah UIN Sunan Kalijaga Yogyakarta.

Sagala, Syaiful. 2006. Metode Belajar Mengajar. Bandung: Alfabeta.

Saifudin Azwar. 1996. Pengantar Psikologi Intelegensi. Jogyakarta: Pustaka Pelajar.

Sanjaya, Wina. 2006. Strategi Pembelajaran Berorientasi Standar Proses Pendidikan. Penerbit: Kencana Prenada Media Group.Jakarta.

Sastromiharjo, Andoyo. 2008. Makalah. Media dan Sumber Pembelajaran. Disampaikan pada Pendidikan dan Pelatihan Profesi Guru Sekolah Menengah Pertama. Universitas Pendidikan Indonesia. Bandung.

Sukidin, Basrowi, Suranto. 2002. Menajemen Penelitian Tindakan Kelas. Penerbti: Insan Cendekia ISBN: 9799048334.

Tim Prima Pena. Kamus Besar Bahasa Indonesia. Gramedia Press.

Uno, B. Hamzah, et. al. 2001.Pengembangan Instrumen Untuk Penelitian. Jakarta: Delima Press.

Wojowasito. 1982. Kamus Umum Lengkap Inggris Indonesia - Indonesia Inggris. Malang: Delta Citra Grafindo. 